\title{
VIOLET-GREEN SWALLOWS AT SASKATOON
}

\author{
DAVID H. WRIGHT, Law Courts, 520 Spadina Crescent East, Saskatoon,
} Saskatchewan. S7K $3 G 7$

The Violet-green Swallow, a bird of the far west and southwest, has been making its way north and east over the past decade or so. It has been sighted at Val Marie. During our annual vacation in central Arizona, I have had a number of opportunities to observe this attractive little bird. On 26 May 1991 I paid a visit to a marsh located north of Saskatoon, approximately $0.8 \mathrm{~km}$ east of No. 16 highway and just south of 70th Street. It is part of a chain of sloughs that are gradually being destroyed by urban sprawl and redevelopment. The land is privately owned. When the sloughs located in this area finally disappear there will be no more wetlands left in the Saskatoon area of comparable quality or variety.

I decided on this date that I would carry out a detailed investigation of the slough boundaries immediately south of 70th Street. This entailed the use of hipwaders and binoculars. I carried a camera with me at the same time but it does not have any telephoto apparatus. The spring and summer of 1991 saw substantial increases in the water level. As a consequence the cattails, bullrushes, and marsh grasses, as well as small shrubs, had prospered and the whole area was very green and was well populated by many species of birds. As I waded around the western edge of the slough I noticed a number of swallows darting about, approximately $12 \mathrm{~m}$ above the surface of the water.

What first attracted my attention was the twittering call. As I stopped to study the flock of 12 to 15 in my binoculars I then noticed several of the male adults were showing prominent green backs. To that point I thought I was seeing a larger than normal group of Tree Swallows but after a few minutes I realized that the birds had white patches on each side of the rump, a field mark characteristic of the Violet-green Swallow. I rechecked my observation several times and was quite satisfied as to what I had seen. I had observed the same markings in Arizona. The swallows seemed to form a loose but cohesive group and were unlike the Tree Swallows that I have observed in the past in smaller groups of perhaps four to six and which seem to fly in essentially separate patterns. The birds moved slowly across the marshland as a loose group, feeding and calling. The twittering call is much more pronounced than one hears from Tree Swallows.

It was only after I began some investigations that it occurred to me that my observations might be something more than routine. When I returned to the marsh at a later date there was no evidence of any Violet-green Swallows nor did I see any for the balance of the summer. I wonder now if they were making an isolated visit to that particular area. Whatever the reason, one may properly assume, given the time of year, that they were local birds and probably breeding somewhere in the area. I would be interested in knowing if any other observers have sighted the violet-green in the Saskatoon district or this far north and east in the province. 